\title{
Soil Bacterial Diversity and Productivity of Coffee - Shade Tree Agro-ecosystems
}

\author{
Rusdi Evizal $^{1}$, Tohari² ${ }^{2}$ Irfan Dwidja Prijambada ${ }^{2}$ Jaka Widada $^{2}$ and Donny Widianto ${ }^{2}$ \\ ${ }^{1}$ Proram Study of Agrotechnology, Faculty of Agriculture, University of Lampung, Gedung Meneng, \\ Jl. Sumantri Brojonegoro No. 1 Bandarlampung 35145, Indonesia, e-mail: rusdievizal@yahoo.com \\ ${ }^{2}$ Department of Soil Science, Faculty of Agriculture, Gadjah Mada University, Bulaksumur, Yogyakarta
}

Received 22 February 2012 / accepted 9 May 2012

\begin{abstract}
Coffee productions should have environmental values such as providing high soil microbial diversity while producing high yield. To examine that purposes, two experimental plots were constucted at benchmark site of Conservation and Sustainable Management of Below-Ground Biodiversity (CSM-BGBD), in Sumberjaya Subdistrict, West Lampung, Indonesia, during 2007-2010. Types of coffee agro-ecosystem to be examined were Coffea canephora with shade trees of Gliricidia sepium, Erythrina sububrams, Michelia champaca, and no shade. Two plots were constructed at 5-years-coffee and 15-years-coffee. Diversity of soil bacteria was determined based on DNA finger printing of total soil bacteria using Ribosomal Intergenic Spacer Analysis (RISA) method. The results showed that: (1) For mature coffee (15 years old), shade-grown coffee agro-ecosystems had higher soil bacterial diversity than those of no shade coffee agro-ecosystem, (2) Shaded coffee agro-ecosystems were able to conserve soil bacterial diversity better than no-shade coffee agro-ecosystem. Soil organic $\mathrm{C}$ and total litter biomass had positive effect on soil bacterial diversity, (3) Types of agro-ecosystem significantly affected the bean yield of 15 years coffee. Coffee agro-ecosystems shaded by legume trees had higher yield than those of non-legume shade and no shade coffee agro-ecosystem, (4) Shannon-Weaver indices of soil bacterial diversity together with weed biomass and N content of coffee leaf had positive effect on coffee bean yield.
\end{abstract}

Keywords: agro-ecosystem, bacterial diversity, coffee, RISA, shade

\section{INTRODUCTION}

Sustainable agro-ecosystem is becoming important issue on coffee production that could be achieved by soil conservation and biodiversity conservation (Conservation International 2001). Biodiversity as a part of ecological aspect covers both aboveground and belowground biodiversity. There are strong interaction between aboveground and belowground communities (He et al. 2008). Plant diversity and soil microbial communities including bacterial diversity are linked. Plant communities govern ecosystems function including structure and function of soil microbe. Such relationship might be driven by plant biomass and productivity (Liu et al. 2008; Lamb et al. 2011).

Moreover, biodiversity including soil bacteria diversity is highly related to agro-ecosystem functioning (Moonen and Barberi 2008). Biodiversity and agro-ecosystem functioning also have impact on stability of agro-ecosystem that need

J Trop Soils, Vol. 17, No. 2, 2012: 181-187 ISSN 0852-257X to be considered to develop of sustainable agroecosystem (Shennan 2008).

Bacterial community is very diverse and predominant in soil. Moreover, soil bacteria plays an important role on ecosystem services such as nutrient cycle and biological N fixation (Rao 2007). Methods to understand the link between soil bacterial diversity and ecosystem functions are needed to be develop to address question of how diversity influences function. Molecular-based methods have been developed to study soil bacterial diversity to overcome problems associated with non-culturable soil bacteria (Kirk et al. 2004). Recently, method of extracting total bacterial community DNA from fresh soil is applied to perform DNA fingerprinting (He et al. 2012).

Planting shade trees are the main measurement for soil conservation in coffee agro-ecosystems beside constructing terrace that is only effectives in the first couple of years in reducing soil loss (Agus 2011; Bernas 2011). Shade trees of legume in partucilar have an ecological function such as litter fall production, $\mathrm{N}$ fixation, reducing soil erosion, utilizing nutrient from deep soil, and improving soil biological processes (Young 1990). 
The objective of this study was to assess coffee agro-ecosystems based on shade tree systems that would sustain soil bacterial diversity and produced high yield of coffee bean.

\section{MATERIALS AND METHODS}

\section{Study Site and Plot}

The research was based on survey and experimental plot of coffee agro-ecosystems, was conducted at benchmark of Conservation and Sustainable Management of Below-Ground Biodiversity (CSM-BGBD), in Sumberjaya Subdistrict, West Lampung, Indonesia, situated at $4^{\circ} 64^{\prime}$ $-5^{\circ} 10^{\prime}$ S and $104^{\circ} 15^{\prime}-104^{\circ} 20^{\prime}$ E. Types of coffee agro-ecosystem to be examined were Coffea canephora with shade trees of Gliricidia sepium, Erythrina sububrams, Michelia champaca, and without shade tree. Two plots consisted of 5 years old and 15 years old coffee trees were established.

The experiment used a randomized completely block design (RCBD) with three replications. Coffee trees were spaced at $2 \times 2 \mathrm{~m}$ and shade trees were spaced at $4 \times 4 \mathrm{~m}$. Manual weeding was done 4 times a year while pruning was 2 times a year. No pesticide was applied. In experimental plot 1 , shrub was cleared and Robusta coffee seedlings were planted with four shade treatments as mentioned above. Size of experiment plot 1 was 0.48 ha consisted of 12 unit plots of $400 \mathrm{~m}^{2}$. Fertilizer dose of 75-25-50 NPK was applied. Plot 2 was a mature Robusta coffee field of 15 years old with the same types of shade trees. Size of experimental plot 2 was 2.4 ha consisted of 12 unit plots of 0.2 ha. Fertilizer of NPK was applied 150-50-100.

\section{Productivity, Soil and Plant Analysis}

Productivity consisted of coffee yield and litter biomass production. Coffee productivity was calculated based on the yield of fresh bean per plot (Haggar et al. 2011). Biomass production (dry weight) was determined based on the production of litter fall, pruning of coffee and shade trees, and weed biomass. Litter fall was sampled using 3 litter traps of $1 \mathrm{X} 2 \mathrm{~m}$ wide per plot. Weed biomass was harvested every 3 months before weeding, based on quadrant of 1X1m wide (Evizal et al. 2009a). At each plots, soils sample were sampled composite at $0-20 \mathrm{~cm}$ depth to analyze organic $\mathrm{C}$ content (Walkley and Black), total N (Kjeldahl), and diversity of total soil bacteria (RISA). To analyze $\mathrm{N}$ content, leaves were sampled from the third and the fourth pairs of leaves from branches located in the middle up the sample trees (Snoeck and Lambot 2004).

\section{Bacterial Analysis}

Molecular analysis was conducted to measure soil bacterial diversity. DNA finger printing of total soil bacteria was done by extracting soil samples (Gabor et al. 2002) using FastDNA Kit for Soil (Biomedical, USA). To extract DNA of bacteria, it took $0.5 \mathrm{~g}$ soil samples and then followed the manufacturer's protocol. Homogenization was done using Fast Prep 24 MP (Biomedical, USA) at the speed of $6.0 \mathrm{~m} \mathrm{sec}^{-1}$ for $40 \mathrm{sec}$. Prior to PCR, the DNA was further purified by using GeneClean Kit (Biomedical, USA).

To analyze soil bacterial diversity, method of Ribosomal Intergenic Spacer Analysis (RISA) was done by using forward primer 1400F (5'> TGYACACACCGCCCGT $<3$ ' and reverse primer 23sR (5'> GGGTTBCCCCATTCRG <3' (Borneman and Triplett 1997). The intergenic spacer region on bacteria DNA was amplified in 20 il PCR mixtures of 10 ìl Mega-Mix-Blue (Microzone, UK), 6 ì sterile distilled water, 1 ì each of $1406 \mathrm{~F}$ and $23 \mathrm{sR}$ primer (25 pmol ì $\left.{ }^{-1}\right), 2$ ìl DNA (25 ng ì $\left.\mathrm{l}^{-1}\right)$. DNA was amplified in a GeneAmp PCR System 9700 (Biosystems, USA) as follows: denaturation of DNA at $95^{\circ} \mathrm{C}$ for $5 \mathrm{~min} ; 30$ cycles of denaturation $\left(95^{\circ} \mathrm{C}\right.$ for $\left.1 \mathrm{~min}\right)$, annealing $\left(53^{\circ} \mathrm{C}\right.$ for $\left.45 \mathrm{sec}\right)$, and elongation $\left(72^{\circ} \mathrm{C}\right.$ for $\left.1 \mathrm{~min} 30 \mathrm{sec}\right)$ with final elongation time of $7 \mathrm{~min}$ at $72^{\circ} \mathrm{C}$.

The PCR products were analyzed in $8 \%$ Polyacrilamide Gel Electrophoreses (PAGE). To make the gel, it took $5.3 \mathrm{ml}$ of $30 \%$ acrilamide, 12.5 ml destilate water, $2 \mathrm{ml} \mathrm{TBE} \mathrm{10X,} 180 \mathrm{ml} 10 \%$ APS and 20 ì 1 TEMED. Then 9 ì 1 PCR products were loaded on polyacrilamide gels in $1 \mathrm{X}$ TAE buffer. Electrophoreses were run with a constant voltage of $100 \mathrm{~V}$ for 6 hours.

\section{Data Analysis}

Intensity of PAGE bands as representation of Operational Taxonomic Unit (OTU) (Cetecioglu et al. 2009) were quantified by Adobe Photoshop software. Using software of Biodiversity Analysis Package, Shannon-Weaver diversity indices $\left(\mathrm{H}^{\prime}\right)$ were calculated based on formula (Ge et al. 2008): $\mathrm{H}^{\prime}=-$ Ó pi(lnpi) where pi $=\mathrm{n} / \mathrm{N}, \mathrm{n}=$ intensity of OTU, $\mathrm{N}=$ total intensity of OTU.

Analysis of variance and Duncan Multiple Range Test was carried out to test effect of type of agro-ecosystems on soil bacterial diversity, soil organic $\mathrm{C}$, total $\mathrm{N}$, weed biomass, $\mathrm{N}$ content of coffee leaf, and coffee bean yield by using SAS 
software. Regression analysis and t-test were performed using SPSS software. Variables of soil organic $\mathrm{C}$, total $\mathrm{N}$, weed biomass, and total litter biomass were regressed with soil bacterial diversity. Variables of soil bacterial diversity, weed biomass, $\mathrm{N}$ leaf content, and total litter biomass were regressed with coffee bean yield. To compare variables between 5-years-coffee and 15-yearscoffee agro-ecosystem, t-test was carried out.

\section{RESULTS AND DISCUSSION}

\section{Soil Bacterial Diversity}

Types of coffee agro-ecosystem influenced soil bacterial diversity which is shown by the profile of DNA bands (Figure 1). Table 1 showed diversity indices of total bacteria DNA extracted from soil samples from different agro-ecosystems based on Shannon-Weaver indices. Types of agro-ecosystem did not affect soil bacterial diversity of 5-yearscoffee. On the contrary, types of agro-ecosystem significantly affected soil bacterial diversity of 15years-coffee. Shaded coffee agro-ecosystems had higher soil bacterial diversity than those of no shade coffee agro-ecosystem. Result of both Duncan and contrast test showed that bacteria diversity from soil of legume (Gliricidia and Erythrina) shade coffee agro-ecosystems were not significantly different with those of non-legume (Michellia) coffee agroecosystem.

\section{Variables Effect on Soil Bacterial Diversity}

As soil decomposer, soil bacterial community is related to soil organic C. soil N. and litter invut.
Status of soil organic C in 5-years-coffee agroecosystems was high $(3.16 \%)$ while in 15 -yearscoffee was moderate $(2.45 \%)$ according to Balai Penelitian Tanah (2005). Status of soil N was low both in 5-years and 15-years-coffee agroecosystems. Based on t-test, weed biomass of 5years-coffee $(9.0 \mathrm{Mg})$ was higher than those of 15 years-coffee agro-ecosystems $(4.9 \mathrm{Mg})$ but total litter biomass (weed, litter fall, and pruning litter) was relatively similar (11.5 Mg for 5-years-coffee and 11.4 for 15-years-coffee agro-ecosystems). Based on Duncan's test, types of coffee agroecosystems did not have effect on soil organic C, total N, and total litter both in 5-years and 15-yearscoffee (Table 2). Souza et al. (2012) reported that soil organic $\mathrm{C}$ and total $\mathrm{N}$ in shaded (agroforest) coffee systems did not differ significantly from fullsun coffee after 13 years of experiment.

Regression analysis result showed that soil organic $\mathrm{C}$ and total litter biomass (litter fall, coffee and shade tree pruning residues, and weed biomass)

Table 1. Diversity indices of soil bacteria from coffee agro-ecosystems.

\begin{tabular}{lcc}
\hline \multirow{2}{*}{$\begin{array}{l}\text { Coffee agro- } \\
\text { ecosystems }\end{array}$} & \multicolumn{2}{c}{$\begin{array}{c}\text { Shannon-Weaver indices } \\
\text { diversity (H') }\end{array}$} \\
\cline { 2 - 3 } & $\begin{array}{c}\text { 5-years- } \\
\text { coffee }\end{array}$ & $\begin{array}{c}\text { 15-years- } \\
\text { coffee }\end{array}$ \\
\hline No shade & $2.60 \mathrm{a}$ & $2.33 \mathrm{~b}$ \\
Gliricidia shade & $2.74 \mathrm{a}$ & $2.76 \mathrm{a}$ \\
Erythrina shade & $2.73 \mathrm{a}$ & $2.86 \mathrm{a}$ \\
Michelia shade & $2.76 \mathrm{a}$ & $2.90 \mathrm{a}$ \\
\hline
\end{tabular}

Note: Means followed by the same letter in a column are not significantly different using Duncan's test at á $=5 \%$.

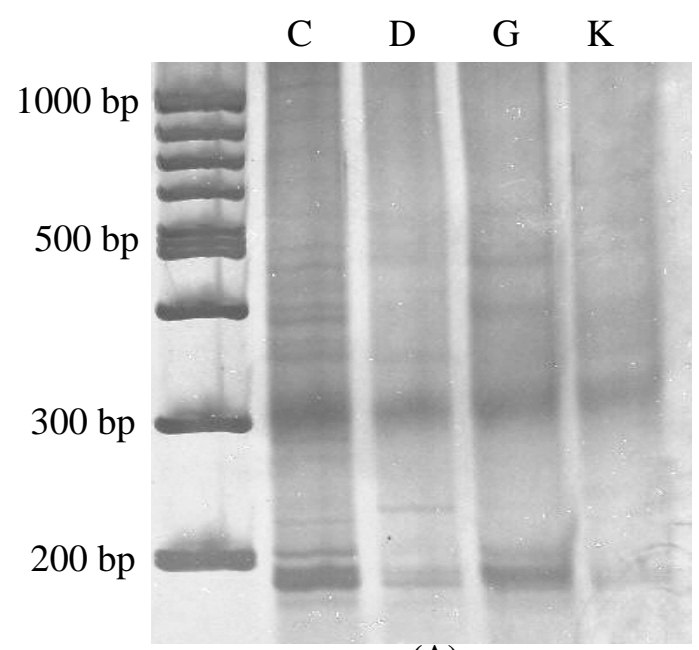

(A)

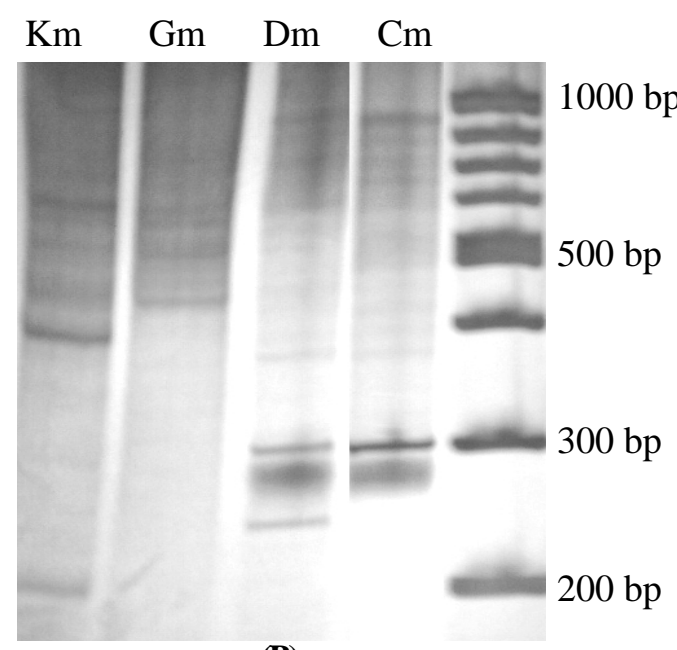

(B)

Figure 1. Profile soil bacterial diversity based on DNA bands $(A=15$-years-coffee with $\mathrm{C}, \mathrm{D}, \mathrm{G}$, $\mathrm{K}=$ Michelia, Erythrina, Gliricidia, no shade tree, B = 5-years-cofee with Km, Gm, $\mathrm{Dm}, \mathrm{Cm}=$ no shade, Gliricidia, Erythrina, Michelia shade tree). 
Table 2. Soil organic C and total N, weed and total litter biomass of coffee agro-ecosystems.

\begin{tabular}{|c|c|c|c|c|}
\hline Agro-ecosystems & $\begin{array}{c}\text { Organic C } \\
(\%)\end{array}$ & $\begin{array}{c}\text { Total N } \\
(\%)\end{array}$ & $\begin{array}{l}\text { Weed biomass } \\
\left(\mathrm{Mg} \mathrm{ha}^{-1} \mathrm{y}^{-1}\right)\end{array}$ & $\begin{array}{c}\text { Total litter biomass } \\
\left(\mathrm{Mg} \mathrm{ha}^{-1} \mathrm{y}^{-1}\right)\end{array}$ \\
\hline \multicolumn{5}{|l|}{ 5-years-coffee } \\
\hline No shade & $3.10 \mathrm{a}$ & $0.24 \mathrm{a}$ & $9.64 \mathrm{a}$ & $11.76 \mathrm{a}$ \\
\hline Gliricidia shade & $3.10 \mathrm{a}$ & $0.24 \mathrm{a}$ & $8.81 \mathrm{~b}$ & $11.20 \mathrm{a}$ \\
\hline Erythrina shade & $3.15 \mathrm{a}$ & $0.26 \mathrm{a}$ & $9.01 \mathrm{ab}$ & $11.77 \mathrm{a}$ \\
\hline Michelia shade & $3.30 \mathrm{a}$ & $0.24 \mathrm{a}$ & $8.55 \mathrm{~b}$ & $11.43 \mathrm{a}$ \\
\hline \multicolumn{5}{|l|}{ 15-years-coffee } \\
\hline No shade & $2.40 \mathrm{a}$ & $0.24 \mathrm{a}$ & $6.93 \mathrm{a}$ & $10.38 \mathrm{a}$ \\
\hline Gliricidia shade & $2.43 \mathrm{a}$ & $0.24 \mathrm{a}$ & $4.44 \mathrm{~b}$ & $10.92 \mathrm{a}$ \\
\hline Erythrina shade & $2.51 \mathrm{a}$ & $0.25 \mathrm{a}$ & $4.33 \mathrm{~b}$ & $12.25 \mathrm{a}$ \\
\hline Michelia shade & $2.46 \mathrm{a}$ & $0.22 \mathrm{a}$ & $3.79 \mathrm{~b}$ & $12.10 \mathrm{a}$ \\
\hline $\mathrm{t}$ calculated (significancy)* & $\begin{array}{c}8.43 \\
(0.00)\end{array}$ & $\begin{array}{c}0.41 \\
(0.69)\end{array}$ & $\begin{array}{c}7.35 \\
(0.00)\end{array}$ & $\begin{array}{c}1.40 \\
(0.89)\end{array}$ \\
\hline
\end{tabular}

Note: Means followed by the same letter in a column are not significantly different using Duncan's test at á $=5 \%$. * Comparing 5-years-coffee with 15-years-coffee.

had positive effect on soil bacterial diversity (Table $3)$. It indicated that soil organic $\mathrm{C}$ and litter input are important for bacteria growth including its diversity. Evizal et al. (2009b) reported that different types of coffee agro-ecosystem produced different composition of litter. Bohlen (2006) reported that changes in plant communities would be followed by changes of litter composition and by changes of soil microbe diversity.

Figure 2 showed regression between total litter biomass and soil bacterial diversity. Litter produced by coffee agro-ecosystems reached $10-13 \mathrm{Mg}$ per ha per year. Soil bacterial diversity increased with the increasing of litter productivity. Continues litter supply from agro-ecosystems stands are important for conserving soil bacterial diversity. YoungMathews et al. (2010) reported that type of agroecosistem affected soil bacterial diversity due to different biomass productivity.

\section{Coffee Productivity and Soil Bacterial Diversity}

$\mathrm{N}$ leaf analysis is important to identify deficiencies that determine coffee growth and production (Snoeck and Lambot 2004). This

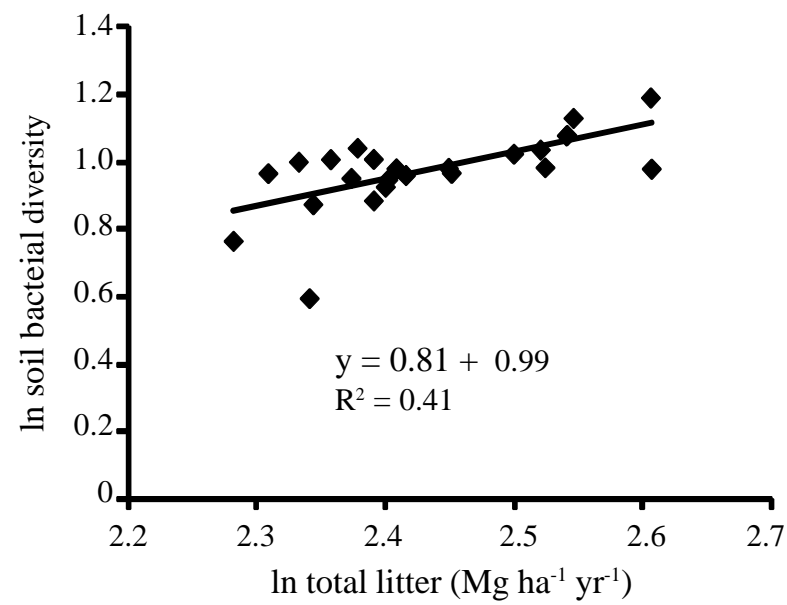

Figure 2. Regression between soil bacterial diversity and litter biomass.

research finding showed that 15 -years-coffee trees with legume trees agro-ecosystems were likely to have higher leaf $\mathrm{N}$ content than those of no shade coffee and non-legume shade coffee agroecosystem. $\mathrm{N}$ leaf content of 5-years-coffee trees were not significantly different (Table 4). Coleman and Whitman (2005) stated that there were linkages between ecosystem processes and plant diversity.

Table 3. Regression of soil bacterial diversity of coffee agro-ecosystems.

\begin{tabular}{lccc}
\hline Variable & Coefficient & $\mathrm{t}$ calculated & Significancy \\
\hline Constant & 0.63 & 1.04 & 0.31 \\
Soil organic C $(\%)$ & $0.26^{*}$ & 1.84 & 0.08 \\
Soil total N (\%) & -2.05 & -1.05 & 0.31 \\
Weed biomass $\left(\mathrm{Mg} \mathrm{ha}^{-1} \mathrm{year}^{-1}\right)$ & -0.04 & -1.55 & 0.14 \\
Total litter biomass $\left(\mathrm{Mg} \mathrm{ha}^{-1} \mathrm{year}^{-1}\right)$ & $0.18^{* *}$ & 4.28 & 0.00 \\
\hline F calculated (significancy) & \multicolumn{3}{c}{$5.49(0.004)$} \\
\hline $\mathrm{R}^{2}$ & 0.54 \\
\hline
\end{tabular}

Note: * Significant at á $5 \%$ and ** at á $0.1 \%$. 
Table 4. N content of coffee leaf.

\begin{tabular}{lclcl}
\hline Coffee agro-ecosystems & $\begin{array}{l}\text { Leaf N }(\%) \\
\text { 5-years-coffee }\end{array}$ & Status & $\begin{array}{l}\text { Leaf N (\%) } \\
\text { 15-years-coffee }\end{array}$ & Status \\
\hline No shade & $2.34 \mathrm{a}$ & Suboptimum & $1.86 \mathrm{c}$ & Deficient \\
Gliricidia shade & $2.73 \mathrm{a}$ & Optimum & $3.12 \mathrm{a}$ & Luxurious \\
Erythrina shade & $2.73 \mathrm{a}$ & Optimum & $2.59 \mathrm{ab}$ & Optimum \\
Michelia shade & $2.51 \mathrm{a}$ & Optimum & $2.07 \mathrm{bc}$ & Suboptimum \\
Mean & 2.58 & Optimum & 2.41 & Optimum \\
\hline t calculated & & & 1.13 & \\
(significancy)* & & & $0.28)$ & \\
\hline
\end{tabular}

Note: Means followed by the same letter in a column are not significantly different using Duncan's test at á $=5 \%$. Status of coffee N content according to Snoeck and Lambot (2004): deficient $(<2 \%)$, optimum $(2.5-3 \%)$, luxurious $(>3.5 \%)$. * Comparing 5-years-coffee with 15-years-coffee.

Table 5. Coffee bean yield of different agro-ecosystems.

\begin{tabular}{lcc}
\hline \multirow{2}{*}{ Coffee agro-ecosystems } & \multicolumn{2}{c}{ Coffee bean yield $\left(\mathrm{kg} \mathrm{ha}^{-1}\right)$} \\
\cline { 2 - 3 } & 5-years-coffee & 15-years-coffee \\
\hline No shade & $1321.5 \mathrm{a}$ & $641.0 \mathrm{c}$ \\
Gliricidia shade & $1534.3 \mathrm{a}$ & $822.4 \mathrm{~b}$ \\
Erythrina shade & $1584.1 \mathrm{a}$ & $961.5 \mathrm{a}$ \\
Michelia shade & $1405.3 \mathrm{a}$ & $512.1 \mathrm{c}$ \\
\hline $\mathrm{t}$ calculated (significancy)* & \multicolumn{2}{c}{$9.11(0.00)$} \\
\hline
\end{tabular}

Note: Means followed by the same letter in a column are not significantly different using Duncan's test at á $=5 \%$. * Comparing 5-years-coffee with 15-years-coffee.

The functional traits of plants such as nitrogenfixing symbionts, are generally strong drivers of ecosystem processes. Snoeck et al. (2000) reported an evidence of the transfer of nitrogen which was fixed by legume trees to coffee trees.

Types of agro-ecosystems did not affect coffee bean yield of 5-years-coffee. It was the second harvest with high yield of coffee bean which was $1.32 \mathrm{Mg} \mathrm{ha}^{-1}$ for no shade coffee and $1.56 \mathrm{Mg} \mathrm{ha}^{-1}$ for shaded coffee. On the contrary, types of agroecosystems significantly affected the bean yield of 15-years-coffee. Coffee agro-ecosystems shaded by legume trees had higher yield than those of nonlegume shade and no shade coffee agro-ecosystem. Between legume trees, coffee agro-ecosystem shaded by Erythrina had higher yield than those of coffee agro-ecosystem shaded by Gliricidia (Table 5). Evizal et al. (2009a) reported that legume shade trees in coffee agro-ecosystems provided ecosystem services such as $\mathrm{N}$ fixation by legume nodulating bacteria (LNB) and leaf fall dynamic that important to improve coffee productivity.

Table 6 shows regression analysis of coffee productivity with some variables including $\mathrm{N}$ content of coffee leaf and soil bacterial diversity. Shannon-Weaver indices of soil bacterial diversity together with weed biomass and $\mathrm{N}$ content of coffee leaf had positive effect on coffee productivity. Soil bacterial diversity including decomposer and LNB plays an important role on ecosystems functioning such as $\mathrm{C}$ cycle and $\mathrm{N}$ cycle that have positive effect on land productivity (Barrios 2007).

Weeds play an ambiguous role on coffee agroecosystems productivity. No doubt, weeds compete with coffee tree on water, nutrient, and space that can decrease coffee bean yield. If weed is controlled properly, coffee yield might not decrease. Yet weeds produce root exudates and biomass that increase soil bacteria activities and soil organic $\mathrm{C}$. This research finding showed that weed biomass, leaf $\mathrm{N}$ content, and soil bacterial diversity were important indicator of coffee productivity.

Using t-test it resulted that for no shade coffee agro-ecosystem, 15-years-coffee had lower soil bacterial diversity than those of 5-years-coffee. However, for shade coffee agro-ecosystems (shaded by legume or non-legume trees), soil bacterial diversity of 15-years-coffee were not significantly different with those of 5-years- coffee agroecosystems (Table 7). This finding indicated that shaded coffee agro-ecosystems conserved soil bacteria diversity better than no shade coffee agroecosystem. 
Tabel 6. Regression of coffee yield and soil bacterial diversity.

\begin{tabular}{lccc}
\hline Variables & Coefficient & $\mathrm{t}$ calculated & Significancy \\
\hline Constant & 6.34 & 1.19 & 0.25 \\
Soil bacterial diversity & $1.03^{*}$ & 2.16 & 0.04 \\
Weed biomass (kg/ha) & $0.75^{* *}$ & 7.22 & 0.00 \\
N leaf content (\%) & $0.96^{* *}$ & 4.15 & 0.00 \\
Total litter biomass (kg/ha/year) & -0.84 & -1.41 & 0.17 \\
\hline F calculated (significancy) & \multicolumn{3}{c}{$19.48(0.00)$} \\
\hline $\mathrm{R}^{2}$ & 0.80 \\
\hline
\end{tabular}

Note: * Significant at á $5 \%$ and ** at á $0.1 \%$.

Table 7. Soil bacterial diversity of 15-years-coffee compared to 5-years-coffee.

\begin{tabular}{lcc}
\hline $\begin{array}{l}\text { Coffee agro- } \\
\text { ecosystems }\end{array}$ & t calculated & Significancy \\
\hline No shade & -2.80 & $0.05^{*}$ \\
Gliricidia shade & -0.97 & 0.39 \\
Erythrina shade & 0.83 & 0.45 \\
Michelia shade & 0.62 & 0.57 \\
\hline
\end{tabular}

Note: * Significant at á $5 \%$.

Shade trees of coffee agro-ecosystems have an important role on biodiversity conservation (Conservation International 2001). Moreover, shade trees are key factor of sustainable coffee plantation (Vaast et al. 2005). This research results showed that coffee agro-ecosystems shaded by legume trees had higher yield and conserved soil bacteria diversity. It also indicated that legume shaded coffee could conserved belowground biodiversity without decreasing coffee yield compare to nonlegume shaded coffee, as suggested by Borkhataria et al. (2012).

\section{CONCLUSIONS}

In the soil of 15-years-coffee agro-ecosystems, shaded coffee had higher soil bacterial diversity than those of no-shade coffee. Shaded coffee agroecosystems were able to conserve soil bacterial diversity better than no-shade coffee agroecosystem. Soil organic $\mathrm{C}$ and total litter biomass (litter fall, coffee and shade tree pruning, and weed biomass) had positive effect on soil bacterial diversity.

Types of agro-ecosystems significantly affected the bean yield of 15-years-coffee. Coffee agro-ecosystems shaded by legume trees had higher yield than those of non-legume shade and no shade coffee agro-ecosystem. Shannon-Weaver indices of soil bacterial diversity together with weed biomass and $\mathrm{N}$ content of coffee leaf had positive effect on coffee bean yield.

\section{ACKKOWLEDGEMENTS}

The authors wish to thank Conservation and Sustainable Management of Below-Ground Biodiversity (CSM-BGBD) Project in Indonesia and Lembaga Pengabdian pada Masyarakat (LPPM) Gadjah Mada University for facilities and funding support.

\section{REFERENCES}

Agus F. 2011. Environmental and sustainability issues of Indonesian agriculture. J Litbang Pert 30 (4): 140-147.

Balai Penelitian Tanah. 2005. Analisis Kimia Tanah, Tanaman, Air, dan Pupuk. Badan Litbang Pertanian. Bogor (In Indonesian).

Barrios E. 2007. Soil biota, ecosystem services and land productivity. Ecol Econ 64: 269-285.

Bernas SM. 2011. Effect of coffee pulp compost and terrace on soil erosion, run off and nutrient loss from coffee plantation in Lahat Regency, South Sumatra. J Trop Soils 16 (2): 161-167. doi: 10.5400/ jts.2011.16.2.161

Bohlen PJ. 2006. Biological invasion: Linking the aboveground and belowground consequences. Appl Soil Ecol 32: 1-5.

Borkhataria R, JA Collazo, MJ Groom and A JordanGarcia. 2012. Shade-grown coffee in Puerto Rico: Opportunities to preserve biodiversity while reinvigorating a struggling agricultural commodity. Agric Ecosyst Environ 149: 164-170.

Borneman J and EW Triplett. 1997. Molecular microbial diversity in soils from Eastern Amazonia: Evidence for unusual microorganisms and microbial population shifts associated with deforestation. Appl Environ Microbiol 63: 2647-2653.

Cetecioglu Z, BK Ince, M Kolukirik, and O Ince. 2009. Biogeographical distribution and diversity of bacterial and archaecal communities within highly polluted anoxic marine sediments from the Marmara sea. Marine Pollut Bull 58: 384-295. 
Coleman DC and WB Whitman. 2005. Linking species richness, biodiversity and ecosystem function in soil ecosystems. Pedobiologia 49: 479-497.

Conservation International. 2001. Conservation principles for coffee production. www. Conservation.org/sites/celb/Documents/ Con_Principles.pdf.

Evizal R, Tohari, ID Prijambada, J Widada and D Widianto. 2009a. Layanan lingkungan pohon pelindung pada sumbangan $\mathrm{N}$ dan produktivitas agroekosistem kopi. Pelita Perkebunan 25: 23-37 (In Indonesian).

Evizal R, Tohari, ID Prijambada, J Widada and D Widianto. 2009b. Biomass production of shadegrown coffee agroecosystems. Proc. International Seminar on Biomass Production and Utilization: Challenges and Opportunities. The University of Lampung, August 3-4. p. 294-304.

Gabor EM, EJ de Vries and DB Janssen. 2002. Efficient recovery of environmental DNA for expression cloning by indirect extraction methods. FEMS Microbiol Ecol 1486: 1-11.

Ge Y, J He, Y Zhu, J Zhang, Z Xu, L Zhang and Y Zheng. 2008. Differences in soil bacteria diversity: Driven by contemporary disturbances or historical contingencies? ISME 2: 254-264.

Haggar J, M Barrios, M Bolanas, M Merlo, P Morago and R Munguia, A Ponce, S Romero, G Soto, C Staver and EMF Virgino. 2011. Coffee agroecosystem performance under full, shade, conventional and organic management regimes in Central America. Agroforest Syst 82: 285-301.

He X, K Wang, W Zhang, Z Chen, Y Zhu and H Chen. 2008. Positive correlation between soil bacterial metabolic and plant species diversity and bacterial and fungal diversity in a vegetation succession on karst. Plant Soil 307: 123-134.

He X, Y Su, Y Liang, X Chen, H Zhu and K Wang, 2012. Land reclamation and sort-term cultivation change soil microbial communities and bacterial metabolic profiles. J Sci Food Agric 92: 1103-1111.

Kirk JL, LA Beaudette, M Hart, P Moutoglis, JN Klironomos, H Lee and JT Trevors. 2004. Methods of studying microbial diversity. J Microbiol Methods 58: 169-188.
Lamb EG, N Kennedy and SD Siciliano. 2011. Effects of plant species richness and evenness on soil microbial community, diversity, and function. Plant Soil 338: 483-495.

Liu ZF, GH Liu, BJ Fu and XX Zheng. 2008. Relationship between plant species diversity and soil microbial functional diversity along a longitudinal gradient in temperate grassland of Hulunbeir, Inner Mongolia, China. Ecol Res 23: 511-518.

Moonen A and P Barberi. 2008. Functional biodiversity: An agroecosystem approach. Agr Ecosyst Environ 127: 7-21.

Rao NSS. 2007. Mikroorganisme Tanah dan Pertumbuhan Tanaman. UI Press. Jakarta (In Indonesian).

Shennan C. 2008. Biotic interactions, ecological knowledge and agriculture. Phil Trans $R$ Soc 363: 717-739.

Snoeck D, F Zapata, and A Domenach. 2000. Isotopic evidence of the transfer of nitrogen fixed by legumes to coffee trees. Biotechnol Agron Soc Environ 4: 95-100.

Snoeck J and C Lambot. 2004. Crop maintenance: Fertilization In: Wintgens JN (ed). Coffee Growing, Processing, Sustainable Production. Wiley-VCH. Weinheim, pp. 246-269.

Souza HN, RGM Goede, L Brussaard, IM Cardoso, EMG Duarte, RBA Fernandes, LC Gomes and MM Pulleman. 2012. Protective shade, tree diversity and soil properties in coffee agroforestry systems in the Atlantic Rainforest biome. Agric Ecosyst Environ 146: 179-196.

Vaast P, R van Kanten, P Siles, B Dzib, N Franck, JM Harmand, and M Génard. 2005. Shade: A key factor for coffee sustainability and quality. Proceeding The $20^{\text {th }}$ International Conference on Coffee Science, 11-15 October 2004, Bangalore, India. p. 887-896.

Young A. 1990. Agroforestry for Soil Conservation. CAB International. Wallingford.

Young-Mathews A, SW Culman, S Sanchez-Moreno, AT O'Geen, H. Ferris, AD Hollander and LE Jackson. 2010. Plant-soil biodiversity relationships and nutrient retention in agricultural riparian zones of the Sacramento Valley, California. Agroforest Syst 80: 41-60. 